Supporting Information

\title{
Tuning upconversion efficiency and spectrum of upconversion nanoparticles through surface decorating of organic dye
}

\author{
Meng Xue ${ }^{\mathrm{a}}$, Cong Cao ${ }^{\mathrm{a}, \mathrm{b}}$, Xiaobo Zhou ${ }^{\mathrm{a}}$, Ming Xü $\mathrm{Xu}^{\mathrm{a}}$, Wei Feng ${ }^{\mathrm{a}^{*}}$, Fuyou $\mathrm{Li}^{\mathrm{a}}{ }^{*}$ \\ aDepartment of Chemistry \& State Key Laboratory of Molecular Engineering of Polymers \& \\ Institute of Biomedicine Sciences \& Collaborative Innovation Center of Chemistry for Energy \\ Materials, Fudan University, 220 Handan Road, Shanghai 200433, P.R. China. \\ ${ }^{\mathrm{b} D e p a r t m e n t}$ of Materials Engineering, College of Materials and Textile, Zhejiang Sci-Tech \\ University, Hangzhou 310018, P.R. China \\ E-mail: fengweifd@fudan.edu.cn and fyli@fudan.edu.cn
}




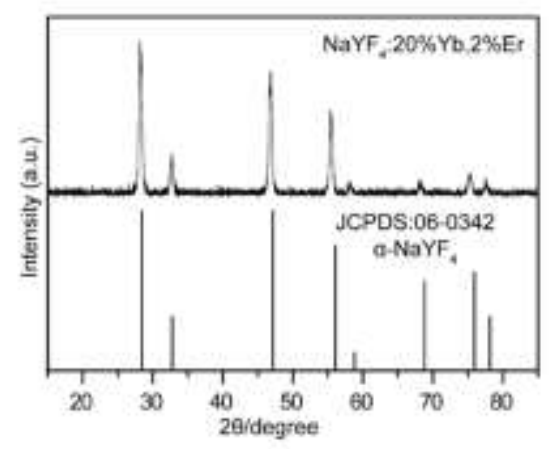

Figure S1: X-ray diffraction (XRD) pattern of $\mathrm{NaYF}_{4}: 20 \% \mathrm{Yb}, 2 \% \mathrm{Er}$ nanoparticles and the standard of cubic phase $\mathrm{NaYF}_{4}$ (JCPDS card No. 06-0342).
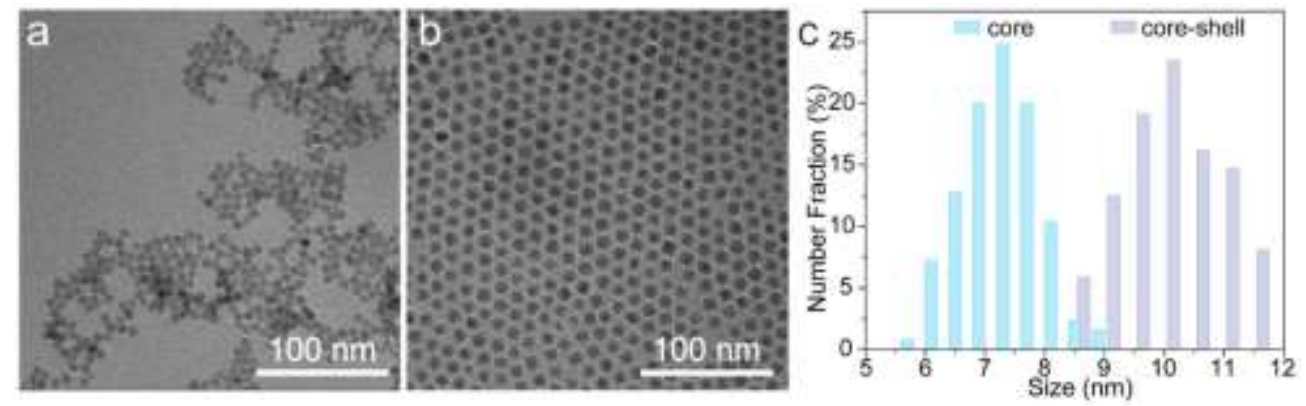

Figure S2: (a) Low-resolution TEM image of $\mathrm{NaYF}_{4}: 20 \% \mathrm{Yb}, 2 \% \mathrm{Er}$ NPs. (b) Low-resolution TEM image of $\mathrm{NaYF}_{4}: 20 \% \mathrm{Yb}, 2 \% \mathrm{Er} @ \mathrm{CaF}_{2}(1: 2) \mathrm{NPs}$. (c) Particle size distribution of core $\mathrm{NaYF}_{4}: 20 \% \mathrm{Yb}, 2 \% \mathrm{Er} \quad \mathrm{NPs}$ and core-shell $\mathrm{NaYF}_{4}: 20 \% \mathrm{Yb}, 2 \% \mathrm{Er} @ \mathrm{CaF}_{2}(1: 2) \mathrm{NPs}$. These data were obtained from the TEM images with more than 100 nanoparticles. 

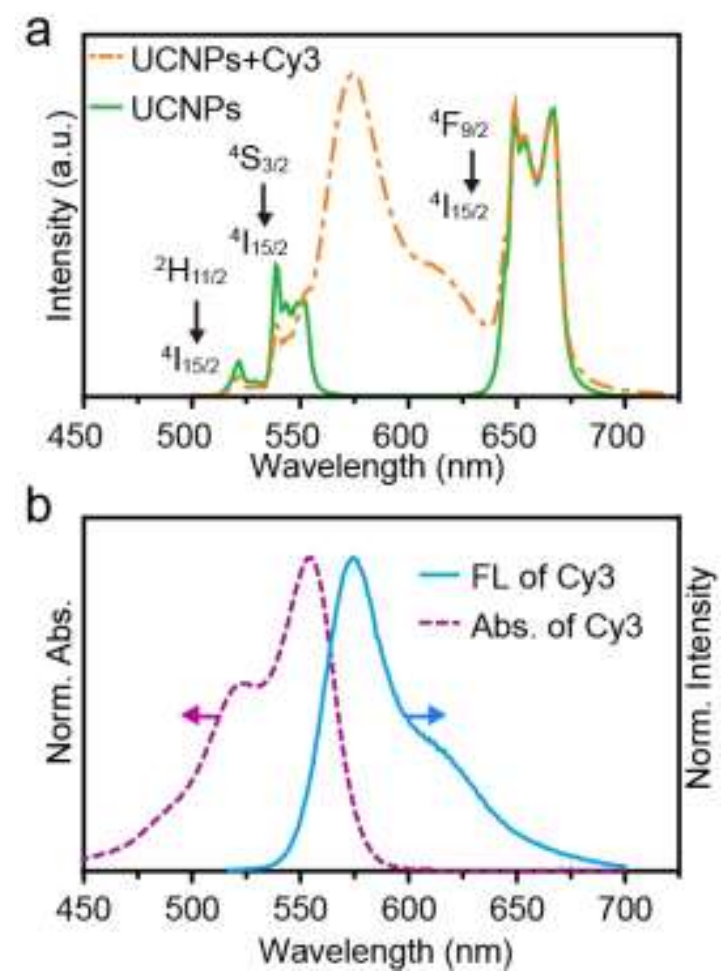

Figure S3: (a) Upconversion luminescence spectrum of $\mathrm{NaYF}_{4}: 20 \% \mathrm{Yb}, 2 \% \mathrm{Er} @ \mathrm{CaF}_{2}(1: 2)$ with (orange dash line) and without (green solid line) Cy3- $-\mathrm{SO}_{3}$ in DMSO excited by a $980 \mathrm{~nm}$ laser. (b) Fluorescence (blue solid line, Ex: $488 \mathrm{~nm}$ ) and absorption (purple dash line) spectrum of $\mathrm{Cy} 3-\mathrm{SO}_{3}$ in DMSO.

We measured the upconversion luminescence spectrum of $\mathrm{NaYF}_{4}: 20 \% \mathrm{Yb}, 2 \% \mathrm{Er} @ \mathrm{CaF}_{2}(1: 2) \mathrm{NPs}$ with $\mathrm{Cy} 3-\mathrm{SO}_{3}$ with different power density (Figure S4a) and converted the luminescence spectrum into CIE 1931 color coordinates (Table S1). The luminescence color changed with different pump power density.

Table S1: The luminescence color coordinates of $\mathrm{NaYF}_{4}: 20 \% \mathrm{Yb}, 2 \% \operatorname{Er} @ \mathrm{CaF}_{2}(1: 2)$ NPs with different pump power density of the $980 \mathrm{~nm}$ laser.

\begin{tabular}{|c|c|c|}
\hline & CIE $x$ & CIE $y$ \\
\hline $5 \mathrm{~W} / \mathrm{cm}^{2}$ & 0.5513 & 0.447 \\
\hline $10 \mathrm{~W} / \mathrm{cm}^{2}$ & 0.5514 & 0.447 \\
\hline $15 \mathrm{~W} / \mathrm{cm}^{2}$ & 0.5505 & 0.4478 \\
\hline $20 \mathrm{~W} / \mathrm{cm}^{2}$ & 0.5503 & 0.448 \\
\hline $25 \mathrm{~W} / \mathrm{cm}^{2}$ & 0.5491 & 0.4491 \\
\hline $30 \mathrm{~W} / \mathrm{cm}^{2}$ & 0.5487 & 0.4495 \\
\hline $35 \mathrm{~W} / \mathrm{cm}^{2}$ & 0.5481 & 0.4502 \\
\hline
\end{tabular}

The dependence of the visible fluorescence intensity on the pump-laser power was calculated as shown in Figure $\mathbf{S 4 b}$. In principle, the UCL emission intensity, $\mathrm{I}_{\mathrm{em}}$, is proportional to the power $n$ of the near-infrared (NIR) exciting pump power. We found 
that the $\mathrm{n}$ value of 539 and $575 \mathrm{~nm}$ is larger than that of $650 \mathrm{~nm}$, which means the change tendency of emission intensity at 539, 575 and $650 \mathrm{~nm}$ with the exciting pump power are different. Because $\mathrm{Cy} 3-\mathrm{SO}_{3}$ received energy from $\mathrm{Er}^{3+}$ ions $\left({ }^{2} \mathrm{H}_{11 / 2}\right.$ and $\left.{ }^{4} \mathrm{~S}_{3 / 2}\right)$, the change tendency of emission at $575 \mathrm{~nm}\left(\mathrm{Cy} 3-\mathrm{SO}_{3}\right)$ is the same with $539 \mathrm{~nm}\left(\mathrm{Er}^{3+}\right.$ ions). And the emission intensity at $539 \mathrm{~nm}$ increased more than $650 \mathrm{~nm}$. So the color of the UCNPs-Cy3-SO 3 system will changed with the power density.
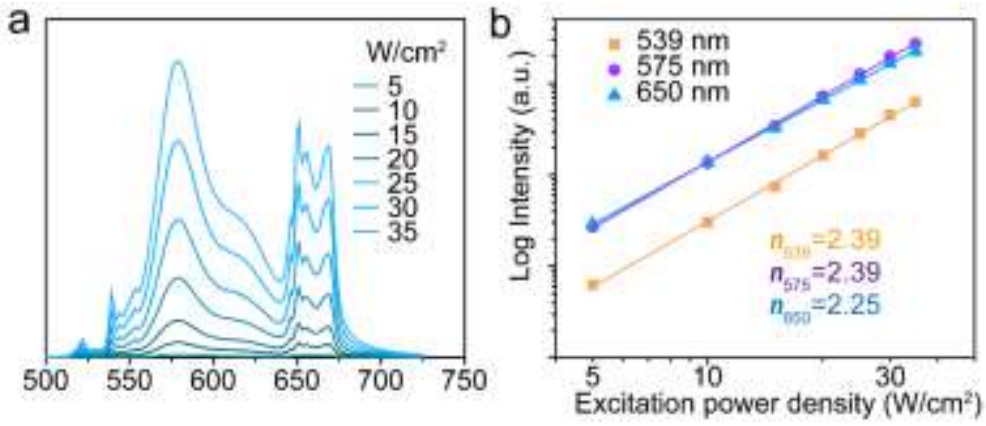

Figure S4: (a) Upconversion luminescence spectrum of $6.67 \mathrm{mM}$ $\mathrm{NaYF}_{4}: 20 \% \mathrm{Yb}, 2 \% \mathrm{Er} @ \mathrm{CaF}_{2}(1: 2) \mathrm{NPs}$ with $5.33 \mu \mathrm{M}$ Cy3-SO 3 in DMSO excited with different power density. (b) Log-log plots of luminescence emission of $\mathrm{NaYF}_{4}: 20 \% \mathrm{Yb}, 2 \% \mathrm{Er} @ \mathrm{CaF}_{2}(1: 2)$ as a function of pump power of the $980 \mathrm{~nm}$ laser.

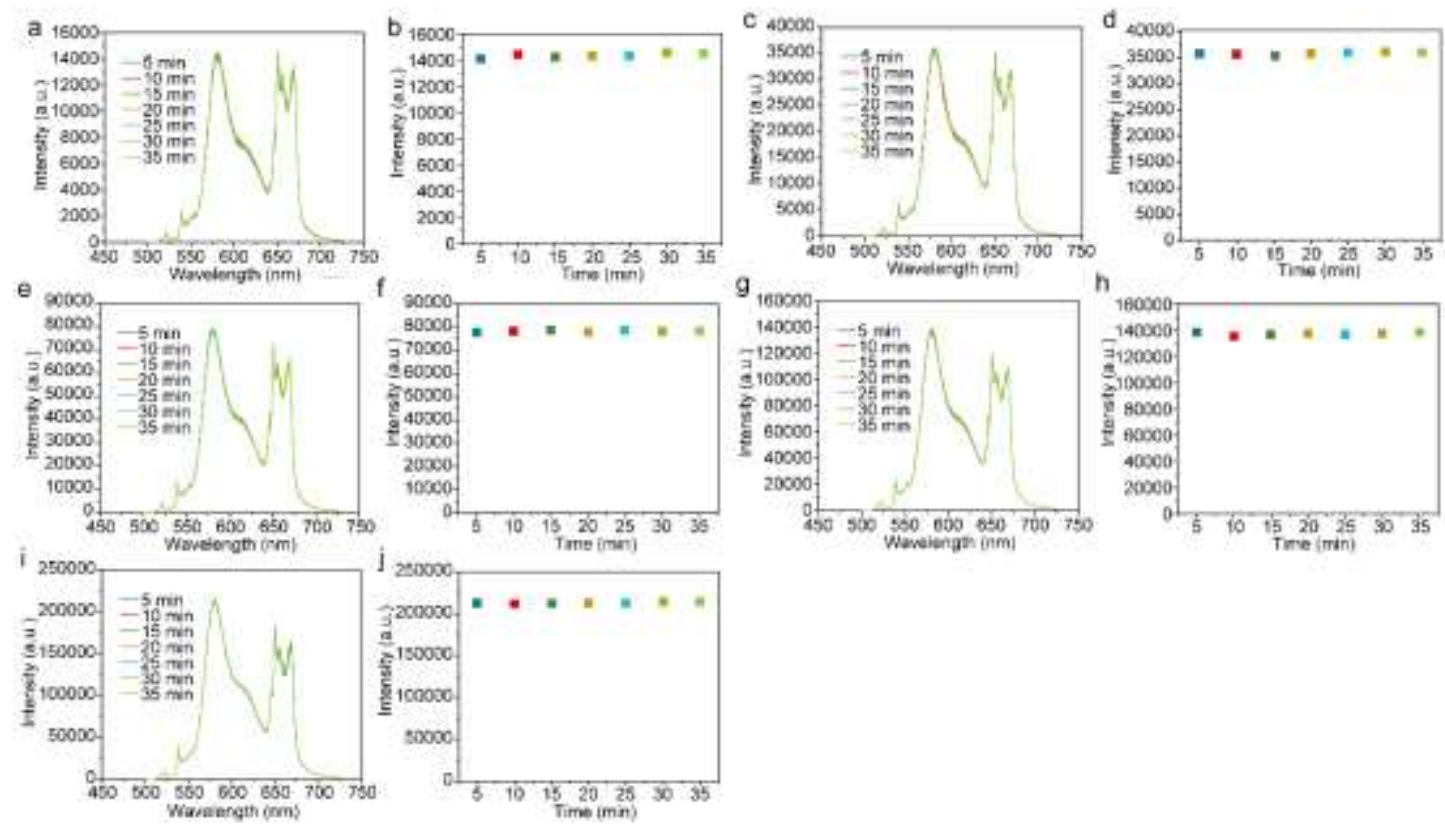

Figure S5: Changes in fluorescence spectra with $5.33 \mu \mathrm{M} \mathrm{Cy3}-\mathrm{SO}_{3}$ in $6.67 \mathrm{mM} \mathrm{UCNPs}$ DMSO solution and the fluorescence intensity of $\mathrm{Cy} 3-\mathrm{SO}_{3}$ at $580 \mathrm{~nm}$ as a function of time with power density $10 \mathrm{~W} / \mathrm{cm}^{2}$ (a, b), $15 \mathrm{~W} / \mathrm{cm}^{2}$ (c, d), $20 \mathrm{~W} / \mathrm{cm}^{2}$ (e, f), $25 \mathrm{~W} / \mathrm{cm}^{2}$ $(\mathrm{g}, \mathrm{h})$, and $30 \mathrm{~W} / \mathrm{cm}^{2}(\mathrm{i}, \mathrm{j})$, respectively. (Ex: $980 \mathrm{~nm}$ ) 


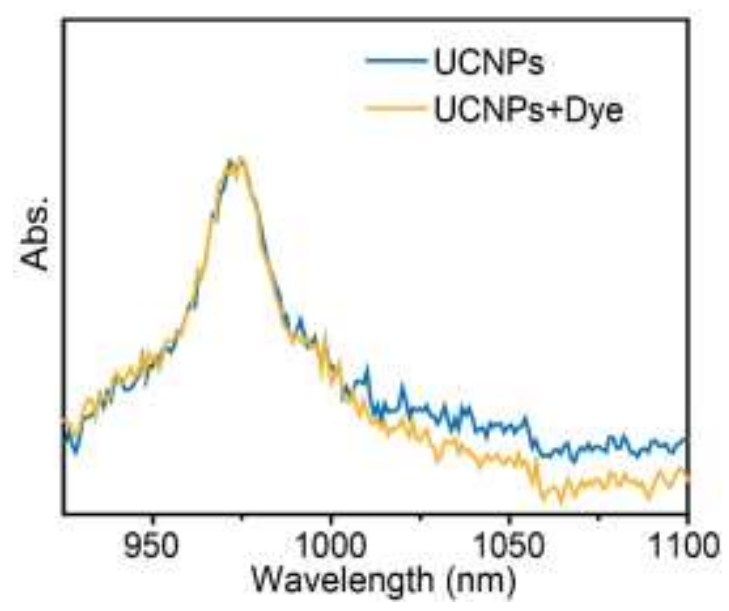

Figure S6: The absorption spectrum of $\mathrm{NaYF}_{4}: 20 \% \mathrm{Yb}, 2 \% \mathrm{Er} @ \mathrm{CaF}_{2}(1: 2)$ with (orange) and without (blue) $\mathrm{Cy} 3-\mathrm{SO}_{3}$ dye.
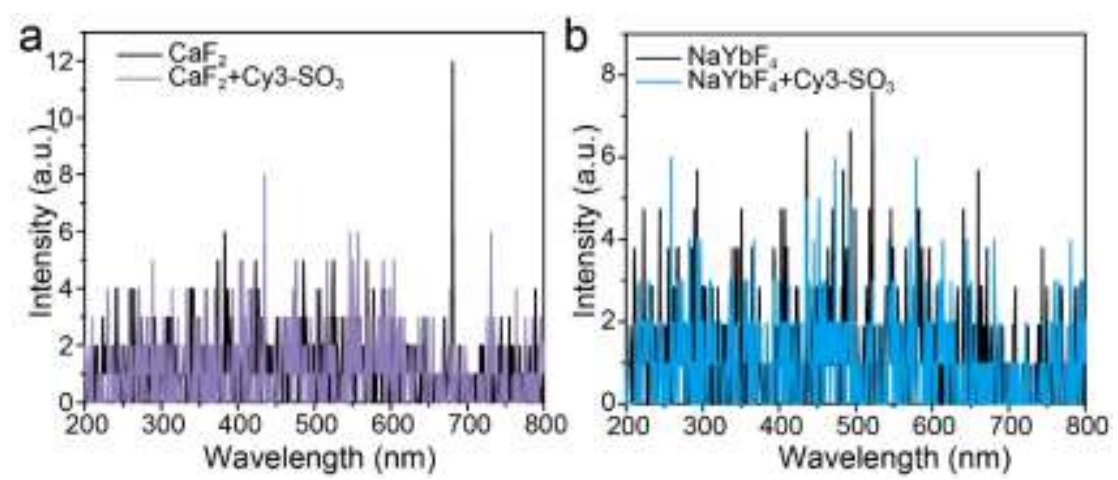

Figure S7: Upconversion luminescence spectrum of $\mathrm{NaYbF}_{4}$ and $\mathrm{CaF}_{2}$ with and without $\mathrm{Cy} 3-\mathrm{SO}_{3}$ in $\mathrm{DMSO}$ excited by a $980 \mathrm{~nm} \mathrm{CW}$ laser. The experiment condition was the same with the experiment condition in Figure 2. 


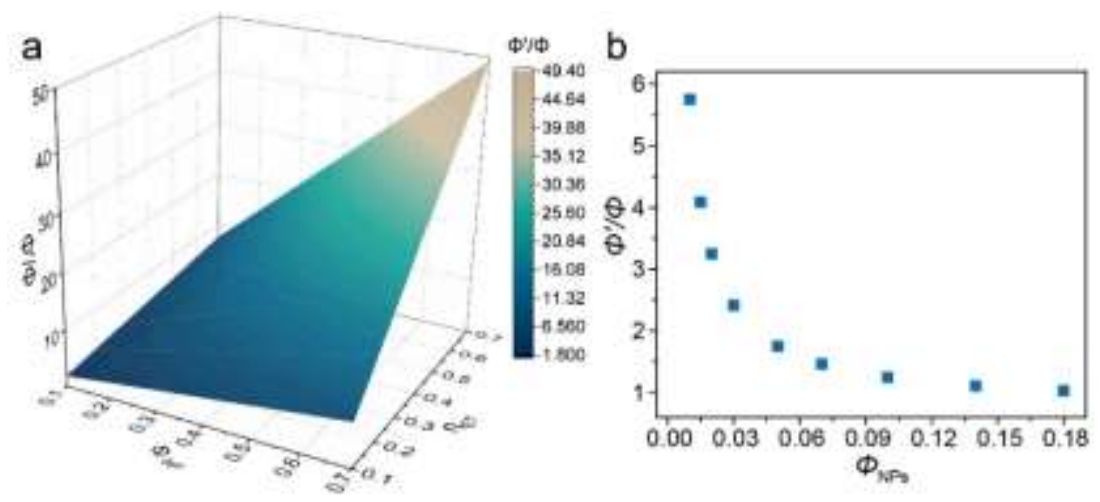

Figure S8: (a) The relationship of $\phi_{\text {dye }}$ and $\eta_{\text {ET }}$ with $\phi^{\prime} / \phi . \phi_{\mathrm{NPs}}$ was assumed as $1 \%$. (b) The relationship of $\phi_{\mathrm{UCNP}}$ with $\phi^{\prime} / \phi . \phi_{\text {dye }}$ and $\eta_{\mathrm{ET}}$ were assumed as $20 \%$ and $25 \%$, respectively.
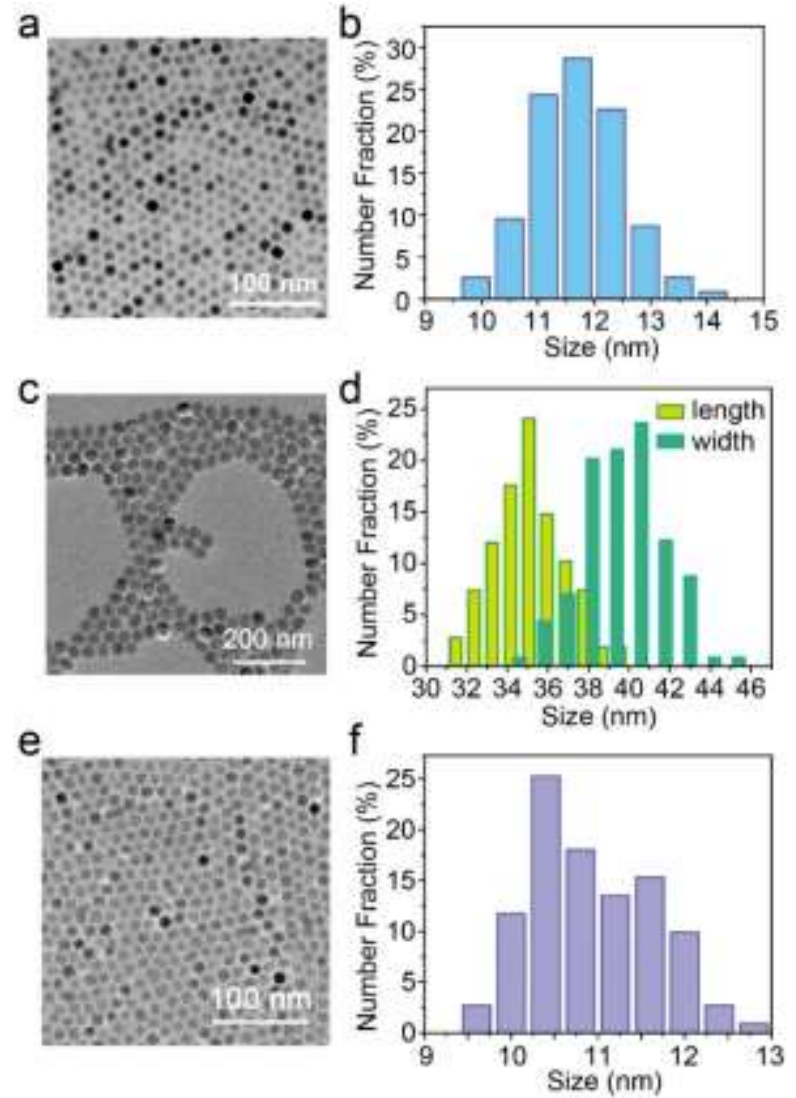

Figure S9: (a) Low-resolution TEM image of $\mathrm{NaYF}_{4}: 20 \% \mathrm{Yb}, 2 \% \operatorname{Er} @ \mathrm{CaF}_{2}(1: 4) \mathrm{NPs}$.

(b) Particle size distribution of $\mathrm{NaYF}_{4}: 20 \% \mathrm{Yb}, 2 \% \mathrm{Er} @ \mathrm{CaF}_{2}(1: 4) \quad \mathrm{NPs}$. (c) Low-resolution TEM image of $\mathrm{NaYF}_{4}: 20 \% \mathrm{Yb}, 2 \% \mathrm{Er}$ NPs. (d) Particle size distribution of $\mathrm{NaYF}_{4}: 20 \% \mathrm{Yb}, 2 \% \mathrm{Er} \quad \mathrm{NPs}$. (e) Low-resolution TEM image of $\mathrm{NaYbF}_{4}: 30 \% \mathrm{~Tb} @ \mathrm{CaF}_{2}: 20 \% \mathrm{~Tb} \quad \mathrm{NPs}$. (f) Particle size distribution of $\mathrm{NaYbF}_{4}: 30 \% \mathrm{~Tb} @ \mathrm{CaF}_{2}: 20 \% \mathrm{~Tb}$ NPs. These data were obtained from the TEM images with more than 100 nanoparticles. 

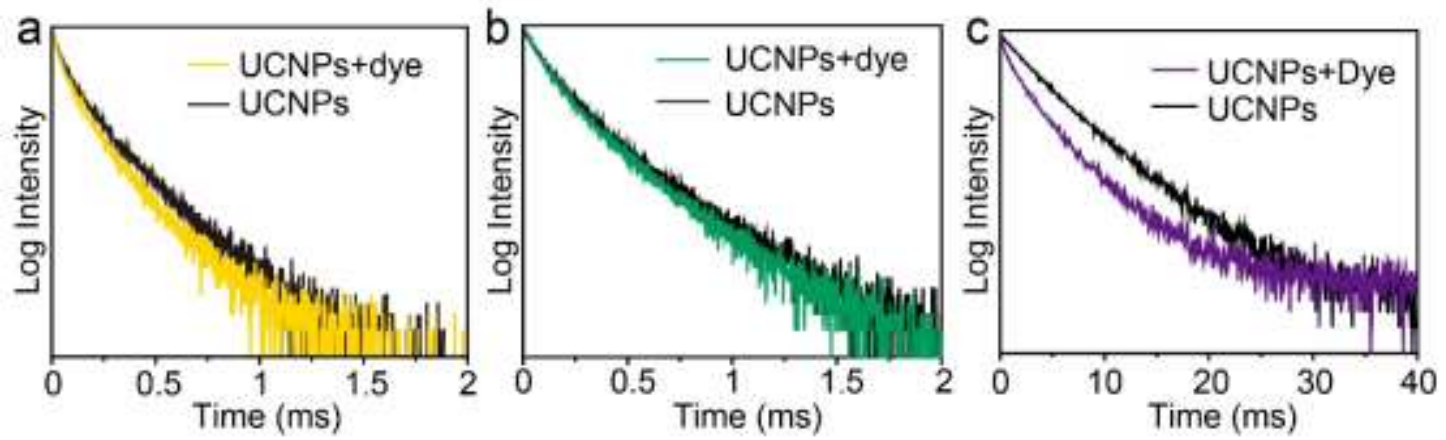

Figure S10: (a) Decay curves of $\mathrm{Er}^{3+}$ ions emission at $540 \mathrm{~nm}$ from $\mathrm{NaYF}_{4}: 20 \% \mathrm{Yb}, 2 \% \mathrm{Er} @ \mathrm{CaF}_{2}(1: 4) \mathrm{NPs}$ with and without $\mathrm{Cy} 3-\mathrm{SO}_{3}$ in DMSO excited by a $488 \mathrm{~nm}$ pulse laser. (b) Decay curves of $\mathrm{Er}^{3+}$ ions emission at $540 \mathrm{~nm}$ from NaYF4:20\% Yb,2\%Er with and without $\mathrm{Cy}_{3}-\mathrm{SO}_{3}$ in DMSO excited by a $488 \mathrm{~nm}$ pulse laser. (c) Decay curves of $\mathrm{Tb}^{3+}$ ions emission at $541 \mathrm{~nm}$ from $\mathrm{NaYbF}_{4}: 30 \% \mathrm{~Tb} @ \mathrm{CaF}_{2}: 20 \% \mathrm{~Tb}(1: 2) \mathrm{NPs}$ with and without $\mathrm{Cy} 3-\mathrm{SO}_{3}$ in $\mathrm{DMSO}$ excited by a $488 \mathrm{~nm}$ pulse laser.

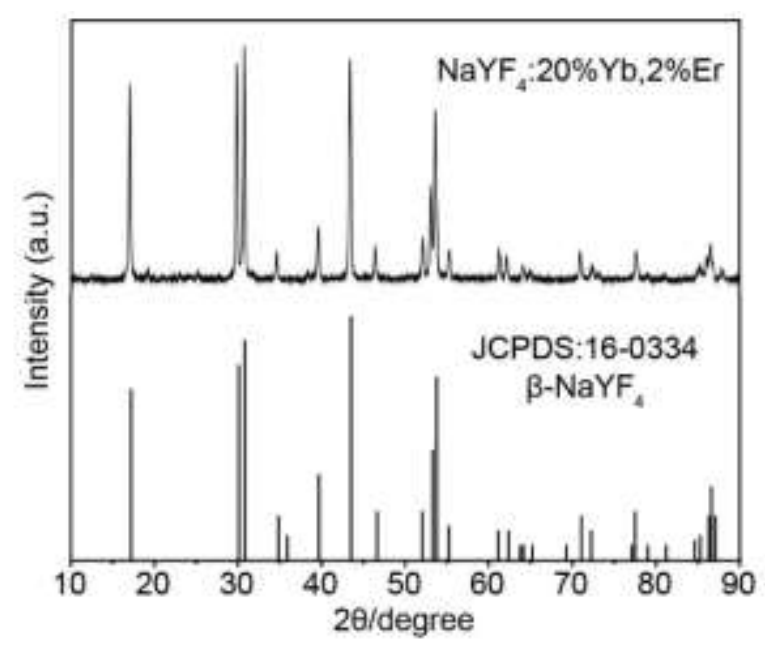

Figure S11: (a) X-ray diffraction (XRD) pattern of hexagonal $\mathrm{NaYF}_{4}: 20 \% \mathrm{Yb}, 2 \% \mathrm{Er}$ nanoparticles and the standard of hexagonal phase $\mathrm{NaYF}_{4}$ (JCPDS card No. 16-0334). 


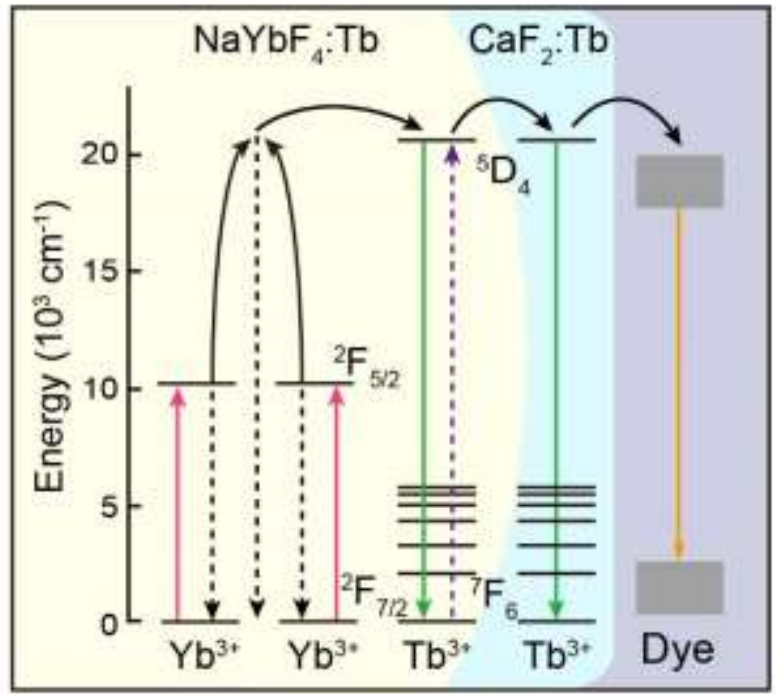

Figure S12: Part of energy level diagram of $\mathrm{Yb}^{3+}$ and $\mathrm{Tb}^{3+}$ doped $\mathrm{NaYbF}_{4}$.
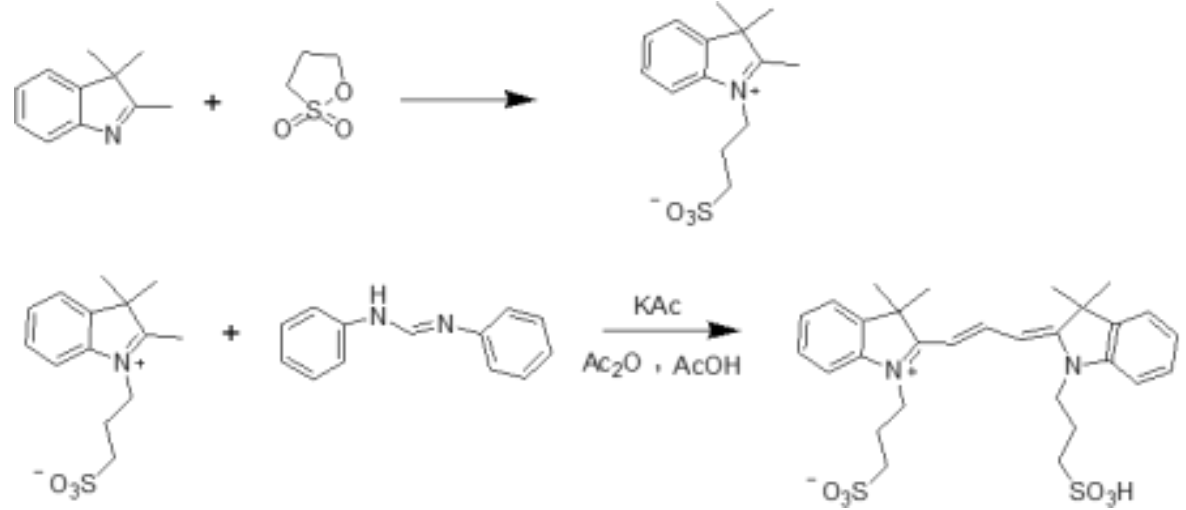

Scheme S1. Synthetic route of $\mathrm{Cy} 3-\mathrm{SO}_{3}$. 


\section{Calculation of the number of $\mathrm{Cy}_{3}-\mathrm{SO}_{3}$ dye on per nanoparticle}

We mixed UCNPs $(6.67 \mathrm{mM}, 1500 \mu \mathrm{L})$ with $0 \mu \mathrm{L}, 1 \mu \mathrm{L}, 2 \mu \mathrm{L}, 3 \mu \mathrm{L}, 4 \mu \mathrm{L}, 5 \mu \mathrm{L}, 6$ $\mu \mathrm{L}, 7 \mu \mathrm{L}, 8 \mu \mathrm{L}$ and $9 \mu \mathrm{L} \mathrm{Cy} 3-\mathrm{SO}_{3}$ dye $\left(10^{-3} \mathrm{M}\right)$, respectively. Then the nanoparticles were centrifuged at $16500 \mathrm{rpm}$ for $40 \mathrm{~min}$. Take out the supernatant and measure the absorption spectra of supernatant. As shown in Figure S13, after centrifugation, there was no absorption peak of $\mathrm{Cy} 3-\mathrm{SO}_{3}$ in the supernatant, indicating that no free dye exists in the supernatant, and all the dripped $\mathrm{Cy} 3-\mathrm{SO}_{3}$ has attached to the UCNPs surface.

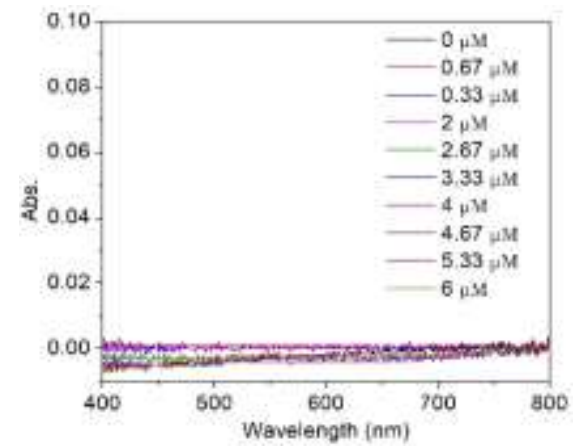

Figure S13: After centrifugation, changes in absorption spectra of supernatant with different addition of $\mathrm{Cy} 3-\mathrm{SO}_{3}$ in UCNPs solution.

We consider the volume of $\mathrm{NaYF}_{4}$ and $\mathrm{NaYF}_{4}: \mathrm{Yb}, \mathrm{Er}$ are approximately equal due to the low doping concentration of $\mathrm{Yb}^{3+}$ and $\mathrm{Er}^{3+}$ ions. The volume of $\mathrm{NaYF}_{4}$ unit cell can be described as

$$
V_{\text {unit cell }}=a^{3}=0.16 \mathrm{~nm}^{3}
$$

The volume of $\mathrm{NaYF}_{4}: \mathrm{Yb}$, Er is

$$
V_{N P}=4 / 3^{*} \pi^{*} r^{3}=187.40 \mathrm{~nm}^{3}
$$

So one $\mathrm{NaYF}_{4}: \mathrm{Yb}$,Er nanoparticle has about 1171 unit cells. A unit cell contains 2 rare earth atoms. So one $\mathrm{NaYF}_{4}: \mathrm{Yb}, \mathrm{Er}$ nanoparticle has about 2342 rare earth atoms. Take $1500 \mu \mathrm{L}$ UCNPs $(6.67 \mathrm{mM})$ with $1 \mu \mathrm{L} \mathrm{Cy3}-\mathrm{SO}_{3}$ dye $\left(10^{-3} \mathrm{M}\right)$ in DMSO as example. $0.01 \mathrm{mmol}$ UCNPs has $0.01 \mathrm{mmol}$ rare earth ions which construct about $2.57 * 10^{15}$ nanoparticles. $1 \mu \mathrm{L} \mathrm{Cy} 3-\mathrm{SO}_{3}\left(10^{-3} \mathrm{M}\right)$ dye solution has $6.02 * 10^{14}$ dye molecule. So there is 0.23 dye attach on a nanoparticle. According to the concentration of UCNPs and Cy3$\mathrm{SO}_{3}$, we calculated the number of $\mathrm{Cy} 3-\mathrm{SO}_{3}$ attached on per UCNPs shown in Table $\mathbf{S 2}$.

Table S2: The relationship between $\mathrm{Cy} 3-\mathrm{SO}_{3}$ concentration and the number of $\mathrm{Cy} 3-\mathrm{SO}_{3}$ on per UCNPs.

\begin{tabular}{ccccccccccc}
\hline $\mathrm{N}_{\mathrm{or}}$ & 0 & 0.23 & 0.46 & 0.69 & 0.92 & 1.15 & 1.38 & 1.61 & 1.84 & 2.07 \\
$\mathrm{c}_{\text {dpe }}(\mu \mathrm{M})$ & 0.00 & 0.67 & 1.33 & 2.00 & 2.67 & 3.33 & 4.00 & 4.67 & 5.33 & 6.00 \\
\hline
\end{tabular}

